\title{
EXPERIMENTAL STUDY OF SELF CURING CONCRETE WITH LIGHT WEIGHT FINE AGGREGATE
}

\author{
S. Suthandradevi \\ (Assistant professor), Department of civil Engineering, \\ Mahendra Institute of Engineering and Technology, Tamil Nadu \\ M. Nivasini \\ Student, Department of civil Engineering, \\ Mahendra Institute of Engineering and Technology, Tamil Nadu
}

\begin{abstract}
Now a day's concrete is main material in construction because of its excellent strength of compression and durability. Depending upon the nature of work the cement, fine aggregate, coarse aggregate and water are mixed in specific proportions to produce concrete. Good environmental atmosphere need concrete achieve desired strength at the minimum period of 28 days. When the concrete is properly curing that the concrete not attain the desired strength. Selfcuring concrete is come under the special concrete. It is very useful for insufficient water areas and reduces the man power etc. In this investigation mix the hydrophilic material in concrete, the use of this hydrophilic in concrete reduce the evaporation or loss of water and also absorb moisture from the atmosphere air and help in concrete for continuous curing. Polyethylene Glycol, Acrylic acid, Paraffin Wax, are some of hydrophilic materials commonly available in market. This experimental study deals with the initial study on the suitability of Pond Ash at different replacement levels as constituent of Concrete for structural work. The study on its Initial Surface Absorption as durability parameter were carried out using Pond Ash, a sustainable material in construction industry, to bring in environmental, ecological \& economic benefits, a major contribution towards social responsibility of researchers. This experimental study to use at the optimum dosage of Polyethylene Glycol (PEG) in concrete. The calculations of mix design for $M$ 20, M-25 \& M -30 grade will achieve. All the properties and calculations were obtained by Indian Standard Code of Specification. The compressive strength will achieved for each grade of concrete. The variations in earlier development of strength will show.
\end{abstract}

Key Words: Self-curing concrete, Water retention, Relative humidity, Hydration, Absorption, Permeable pores, Water permeability

\section{INTRODUCTION}

Better performance and durability is achieved in structures by curing it properly. After mixing, placing and finishing by external curing this is achieved in conventional curing. Curing by self or curing internally is one of the methods which are used to give more moisture in concrete for more effective hydration of cement and reduced selfdesiccation.

\section{A. Methods of self curing}

For internal curing of concrete there are two major methods which is used currently. The first method uses saturated porous lightweight aggregate (LWA), which can replace the water consumed by chemical shrinkage during cement hydration by supplying an internal source of water. IN the second method of internal curing poly-ethylene (PEG) is used which reduces the evaporation of water from the concrete surface and it also helps in water retention.

\section{B. Mechanism of Internal Curing}

Evaporation of moisture takes place continuously from an exposed surface due to the difference in chemical potentials (free energy) between the vapor and liquid phases. The hydrogen bonds are mainly formed with water molecules by the addition of polymers to the mix and the reduction chemical action of the molecules tends to decrease the vapor pressure, thus reducing the rate of evaporation.

\section{Significance of Self-curing}

The demand for curing water can be much greater than that in a conventional ordinary Portland cement concrete when the mineral admixtures react completely in a blended cement system. Significant 


\section{International Journal of Engineering Applied Sciences and Technology, 2019 \\ Vol. 4, Issue 5, ISSN No. 2455-2143, Pages 252-258 \\ Published Online September 2019 in IJEAST (http://www.ijeast.com)}

autogenous deformation and (early-age) cracking may result when this water is not readily available. Empty pores are created within the cement paste due to the chemical shrinkage occurring during cement hydration, leading to early age cracking by shrinkage and reduction in internal relative humidity.

D. Potential Materials for Internal Curing (IC)

The following materials can provide internal water reservoirs:

- Lightweight Aggregate (natural and synthetic, expanded Shale)

- Super-absorbent Polymers (SAP) (60-300 nm size)

- $\quad$ SRA (Shrinkage Reducing Admixture) (propylene glycol)

E. Advantages Of Self Curing

- The method called internal curing(IC) provides water to hydrate all the cement, accomplishing what the mixing water alone cannot do.

- For keeping the relative humidity (RH) high, and self-desiccation from occurring it provides water.

- Larger autogenous shrinkage is avoided.

- The mortar or concrete strength is maintained at the earlier age (12 to 72 hrs.) strains induced internally and externally above the level causes cracking.

- The deficiencies of external curing, both human related is avoided (critical period when curing is required in the first 12 to 72 hours) and hydration.

\section{F. Polyethylene Glycol}

Polyethylene glycol is a condensation polymer of ethylene oxide and water with the general formula $\mathrm{H}(\mathrm{OCH} 2 \mathrm{CH} 2) \mathrm{nOH}$, where $\mathrm{n}$ is the average number of repeating oxyethylene groups typically from 4 to about 180 . The abbreviation (PEG) is termed in combination with a numeric suffix which indicates the average molecular weights. One common feature of PEG appears to be the water-soluble nature. Polyethylene glycol is non-toxic, odorless, neutral, lubricating, non-volatile and non-irritating and is used in a variety of pharmaceuticals.

\section{LITERATURE REVIEW}

\section{S. Ravikumar, Selvamony}

The High Strength Concrete's cement content is generally high which often leads to higher shrinkage and greater evaluation of heat of hydration besides increase in cost. A partial substitution of cement by an industrial waste, such as kiln ash improves the properties of fresh and hardened concrete and it is economical too, and increases the durability the disposal of waste is done safely thereby protecting the environment from pollution.

The replacement level of cement with kiln ash to about $25-35 \%$ is restricted. An Experimental investigation was conducted to make a comparative study on the properties of High Performance Concrete in combination with kiln ash $(25 \%$ and $50 \%$ replacement) and without kiln ash (control concrete) in aggressive and normal environment using self curing instead of water curing. Finally it is concluded that High Performance Kiln ash self curing Concrete performs well both in normal and aggressive conditions when compared to control cement concrete without kiln ash.

\section{Manoj Kumar and D. Maruthachalam}

The process of Curing is done for maintaining proper moisture content particularly within 28 days to promote optimum cement hydration immediately after placement. Vital role is played by curing In the development of concrete's microstructure and pore structure. Curing by proper means is not practically possible in most of the cases. Curing of concrete externally is not necessary in self curing. Water wasted through evaporation is reduced by using the concept of self curing. As defined by ACI, Self or internal curing refers that because of the availability of additional internal water that is not part of the mixing water hydration of cement occurs. Self curing distributes the extra curing water (uniformly) throughout the entire 3-D concrete microstructure for maintaining saturation of the cement paste during hydration, avoiding selfdesiccation (in the paste) and reducing autogenous shrinkage it is more readily available. The grade that was selected is M40. The Super Absorbent Polymer (SAP) is used as a self curing material and the application of wax based membrane curing compound on the demoulded concrete specimens. The effect variation occurs due to Compressive Strength, Splitting Tensile Strength and Flexural Strength the self curing agents on different dosages were studied and then compared with that of conventional cured concrete.

Nirav R Kholia, Prof. Binita A Vyas, Prof. T. G. Tank

Curing influences the properties of harden concrete and durability since it has a remarkable effect on the hydration of the cement. The development of the new curing techniques and construction chemicals such as Membrane curing compounds, Self-curing agents, Wrapped curing, Accelerators, 


\section{International Journal of Engineering Applied Sciences and Technology, 2019 \\ Vol. 4, Issue 5, ISSN No. 2455-2143, Pages 252-258 \\ Published Online September 2019 in IJEAST (http://www.ijeast.com)}

compounds used for water proofing etc are due to the advancements in the construction and chemical industry. With the growing scale of the project conventional curing methods have proven to be costlier because there are many practical issues. Membrane curing compound and self curing agents up to some extent is used in inaccessible areas, vertical structures, and water scare areas in replacement with this. These are generally compared and adopted in construction industry with conventional water curing method.

\section{Patel manishkumar dahyabhai, prof.}

High compressive strength and durability is greater is concrete so it is consumed more in the world. For attaining good heat of hydration and high strength conventional concrete is cured for 28 days. If the curing is done improperly it affects the strength and durability. The concrete which is used in arid areas and where the presence of fluorides affects the characteristics of concrete is called self curing concrete. The usage of polyethylene Glycol (PEG 400) as an admixture in conventional concrete we can achieve high strength and hydration of concrete. By varying the percentage of PEG from $0 \%$ to $2 \%$ of the weight of the cement the effect of PEG on modulus of rupture, split tensile strength, compressive strength is studied. PEG400 could help with self-curing by giving strength on part with conventional curing as per the study. The workability is not compromised even $1 \%$ of PEG was optimum for M20 for achieving maximum strength. The water soluble polymers used in concrete have improved performance of concrete in the indicated test results.

\section{Vollenweider, Basil gnanappa}

Precast concrete is advantageous for several reasons: shrinkage and creep can be reduced, fir controlling the deflections, improving the quality, material availability can be improved and erection methods are similar to that for steel and thus total construction time is significantly reduced. The ability is one of the properties of the concrete that makes pre casting economically feasible, under the proper conditions, to gain compressive strength extremely rapidly. The focus of the paper is mainly based on the methods used variously and is currently available for accelerating the curing of concrete, particularly for precast concrete applications.

\section{SCOPE AND OBJECTIVE}

- To obtain the optimum level of high early development strength by Self-curing concrete.

- The scope of this experiment studies the effect of polyethylene glycol (PEG 400) on Self-curing concrete.

- Self-curing concrete reduces the time of curing and also improves the quality of concrete.

- To make a building free from environmental pollution, the fly ash can be used in concrete.

\section{EXPERIMENTAL PROGRAMME}

The experimental investigation was designed adding PEG 400 at $1.5 \%$ and fine aggregate fly ash in nominal concrete for investigates the strength of self curing concrete. The experimental investigation was aimed to study the compressive strength, workability, split tensile strength and modulus of rupture. To study this investigation the grade of concrete for M20 and M30. The scheme of experimental program is given in

*The size of the cube is $150 \times 150 \times 150 \mathrm{~mm}$.

\# The size of the cylinder is $150 \mathrm{~mm}$ in dia and 300 $\mathrm{mm}$ in

height.

The size of the prism is $100 \times 100 \times 400 \mathrm{~mm}$

\section{MATERIALS USED}

The different materials used in this investigation are

A. Cement:

The 53 grade ordinary Portland cement was used in this experimental confirming IS: 12269: 2000.

B. Fine aggregate:

Below $4.36 \mathrm{~mm}$ size of fine aggregate used was obtained from a near by river source. Conforming the fine aggregate to zone III according to IS: 383-1970 was used. And the fly ash was used as fine aggregate in concrete for partially replaced.

C. Coarse aggregate:

The coarse aggregate according to IS: 383-1970 was used in this project. Maximum coarse aggregate size used is 20 $\mathrm{mm}$.

D. Polyethylene Glycol-400:

Polyethylene glycol is a moisturized 


\section{International Journal of Engineering Applied Sciences and Technology, 2019 Vol. 4, Issue 5, ISSN No. 2455-2143, Pages 252-258 \\ Published Online September 2019 in IJEAST (http://www.ijeast.com)}

polymer of ethylene oxide and water with the general formula $\mathrm{H}(\mathrm{OCH} 2 \mathrm{CH} 2) \mathrm{nOH}$, where $\mathrm{n}$ is the average number of repeating oxyethylenegroups typically from 4 to about 180 . The abbreviation (PEG) is termed in combination with anumeric suffix which indicates the average molecular weight. PEG appears to be the water-soluble nature, it is the common future of PEG. The PEG-400

Molecular Weight 400, Appearance of the PEG 400 Clear liquid, $\mathrm{pH}$ value of PEG 57, Specific Gravity 1.126.

E. Water:

Used the portable water in this investigation.

\section{CASTING PROGRAMME:}

Stanted specimens were casted done as per IS:10086-1982, and design mix was designed according to IS:10262:2009. The mixing, compacting of concrete are done according to IS 516: 1959. The conventional concrete samples of cubes, cylinders and prisms were cured in water at 28 days and the specimens with PEG400 and fly ash were cured for 28 days at room temperature by placing them in shade. The M20, and M30 grades of concrete were designed and the material required per cubic meter of concrete is below in Table 1, and table 2

Table:1 M20 grade concrete mix design

\begin{tabular}{|l|l|l|l|}
\hline Cement & $\begin{array}{l}\text { Fine } \\
\text { aggregate }\end{array}$ & $\begin{array}{l}\text { Coarse } \\
\text { aggregate }\end{array}$ & Water \\
\hline $\begin{array}{l}348.32 \\
\mathrm{~kg} / \mathrm{m}^{3}\end{array}$ & $569.41 \mathrm{~kg} / \mathrm{m}^{3}$ & $\begin{array}{l}1226.16 \\
\mathrm{~kg} / \mathrm{m}^{3}\end{array}$ & $\begin{array}{l}185.07 \mathrm{lit} / \\
\mathrm{m}^{3}\end{array}$ \\
\hline 1 & 1.63 & 3.52 & 0.53 \\
\hline
\end{tabular}

Table .2 Mix Design for M-30 Grade Concreteb

\begin{tabular}{|c|c|c|c|}
\hline Cement & $\begin{array}{c}\text { Fine } \\
\text { aggregate }\end{array}$ & $\begin{array}{c}\text { Coarse } \\
\text { aggregate }\end{array}$ & Water \\
\hline $\begin{array}{c}413.33 \\
\mathrm{~kg} / \mathrm{m}^{3}\end{array}$ & $\begin{array}{c}515.46 \\
\mathrm{~kg} / \mathrm{m}^{3}\end{array}$ & $\begin{array}{c}1065.42 \\
\mathrm{~kg} / \mathrm{m}^{3}\end{array}$ & $\begin{array}{c}185.07 \\
\mathrm{lit} / \mathrm{m}^{3}\end{array}$ \\
\hline 1 & 1.25 & 2.57 & 0.44 \\
\hline
\end{tabular}

\section{TESTING}

\section{A. Slump Test \& Compaction Factor.}

The Slump test was conducted for know workability and consistency of concrete. It $\mathrm{w}$ is very useful to mason for easy working. Due to this test know the uniformity of concrete. As well as compaction factor also calculate the workability and consistency of concrete. If workability is low the employ do the work very difficult. $t$ very important test for construction. $7.2 \quad 7.2$ Compressive strength:

the compression testing machine capacity $3000 \mathrm{KN}$. It should be cleaned and other materials are removed from the machine. The cube specimens were fixed on the platform of compression machine. The top and bottom surface of the cube should be tight and fixed. The load applied on the surface of the specimen the load applied up to the ultimate load. After that the load noted.

The characteristic strength of concrete calculated by the ratio between the applied to area of the top surface of cube.

\section{B. Split tensile strength:}

The cylinder specimens also tested on compression testing machine, the capacity of the machine $3000 \mathrm{KN}$.The bearing surface of compression testing machine was should be clean and looses other sand or other material removed from the surface of the specimen. The load applied was increased gradually at a constant rate upto the resistance of the specimen to the increasing load breaks down and can not be sustained aat longer. The ultimate load applied on specimen was recorded.

Split tensile strength of the concrete $=2 \mathrm{P} / \pi \mathrm{DL}$, where $\mathrm{P}=\mathrm{load}$, $\mathrm{D}=$ cylinder dia, $\mathrm{L}=$ cylinder length 


\section{Modulus of rupture:}
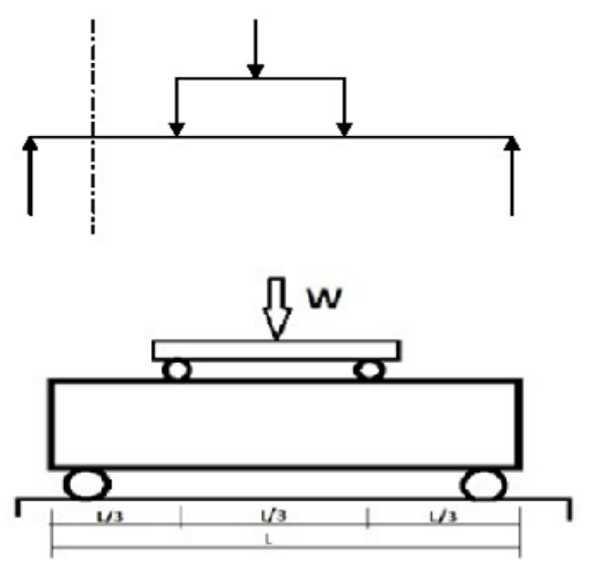

Fig: 1: Modulus of rupture

The beam specimens were tested on flexural testing machine for two-point loading to create a pure bending. The bearing surface of flexural testing machine was should be clean and looses other sand or other material removed from the surface of the specimen. The two point bending load applied was increased gradually at a constant rate until the specimen breaks down and not can be sustained at longer. The ultimate load applied on specimen was recorded.

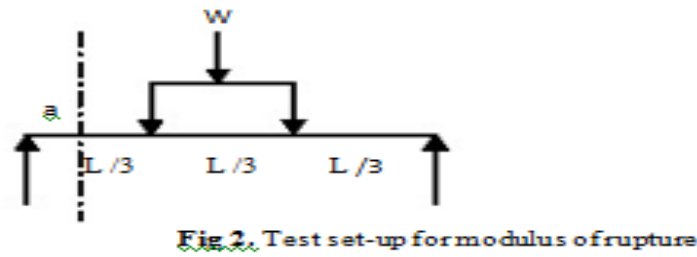

If the specimen breaks at the centre third of the span then the modulus of rupture is given by frup. $=(\mathrm{WL}) /\left(\mathrm{bd}^{2}\right)$

If the prism breaks at a distance ' $a$ ' from any of the supports then the modulus of rupture is given by rupture. $=(3 \mathrm{Wa}) /(\mathrm{bd} 2)$, where $\mathrm{W}=$ load at failure, $\mathrm{L}=$ specimen length $\mathrm{b}=$ specimen width , $\mathrm{d}=$ specimen depth

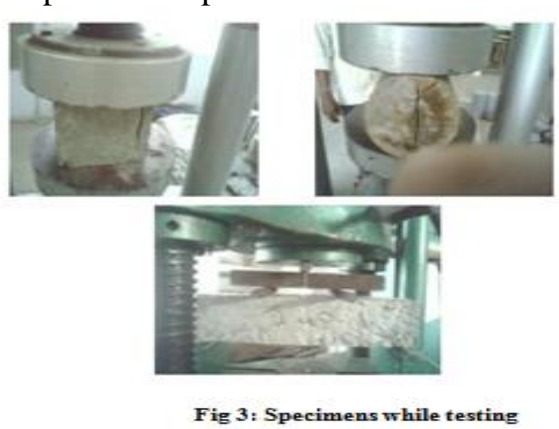

\section{RESULTS \& DISCUSSION}

A. Slump and Compaction factor test:

The results of the Slump \& Compaction factor test were represented in Table 3. The graphical representation of the Slump \& Compaction factor results is shown in Fig 4 and Fig 5 respectively. As the $\%$ of PEG400 is increased the slump and compaction factor is found to increase. But, the rate of increase

Table 8.1 Compressive Strength - 20\%

Replacement of Fly Ash

\begin{tabular}{|c|c|c|c|c|c|c|}
\hline \multirow{2}{*}{ S.no } & \multirow{2}{*}{ Mix } & \multicolumn{5}{|c|}{ Days } \\
\cline { 3 - 7 } & & $\begin{array}{c}\mathbf{3} \\
\text { days }\end{array}$ & $\begin{array}{c}\mathbf{7} \\
\text { days }\end{array}$ & $\begin{array}{c}\mathbf{1 4} \\
\text { days }\end{array}$ & $\begin{array}{c}\mathbf{2 1} \\
\text { days }\end{array}$ & $\begin{array}{c}\mathbf{2 8} \\
\text { days }\end{array}$ \\
\hline 1. & $\mathrm{M}_{20}$ & 14.55 & 17.77 & 20.33 & 21.55 & 23.11 \\
\hline 2. & $\mathrm{M}_{30}$ & 17.44 & 22.22 & 25.88 & 27.55 & 31.33 \\
\hline
\end{tabular}

Table 8.2 Compressive Strength For 30\% Replacement of Fly Ash

\begin{tabular}{|l|l|l|l|l|l|l|}
\hline S.no & Mix & \multicolumn{5}{|c|}{ Days } \\
\cline { 4 - 7 } & & $\begin{array}{l}\mathbf{3} \\
\text { days }\end{array}$ & $\begin{array}{l}\mathbf{7} \\
\text { days }\end{array}$ & $\begin{array}{l}\mathbf{1 4} \\
\text { days }\end{array}$ & $\begin{array}{l}\mathbf{2 1} \\
\text { days }\end{array}$ & $\begin{array}{l}\mathbf{2 8} \\
\text { days }\end{array}$ \\
\hline 1. & $\mathrm{M}_{20}$ & 15.55 & 19.33 & 21.11 & 26.67 & 26.77 \\
\hline 2. & $\mathrm{M}_{30}$ & 22.22 & 24.33 & 29.77 & 30.22 & 32.55 \\
\hline
\end{tabular}

The graph shows the variation of mix and days.

Graph 1: Compressive strength for $20 \%$ replacement

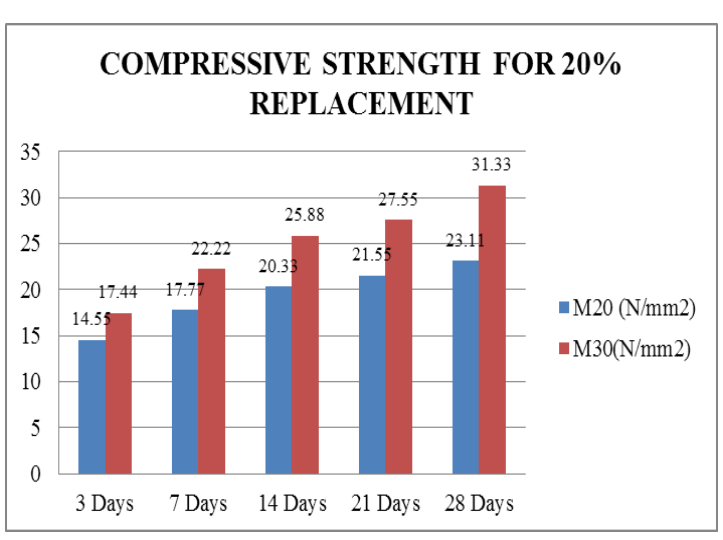

Graph 2: Compressive strength for $30 \%$ replacement 


\section{International Journal of Engineering Applied Sciences and Technology, 2019 \\ Vol. 4, Issue 5, ISSN No. 2455-2143, Pages 252-258 \\ Published Online September 2019 in IJEAST (http://www.ijeast.com)}

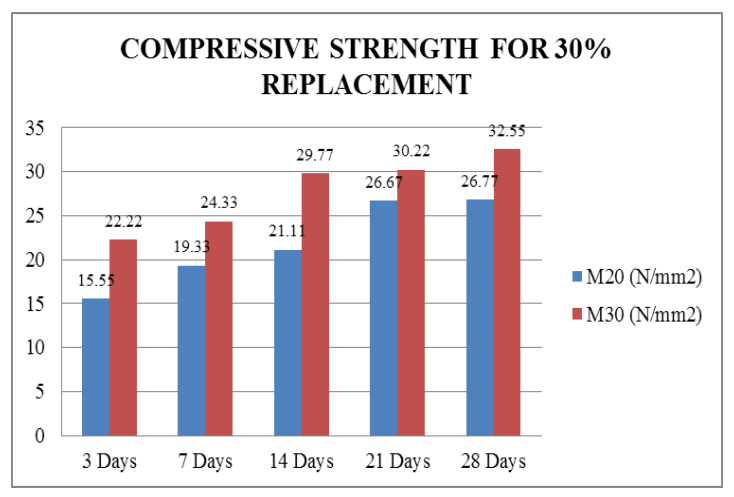

B. Split Tensile Strength Test:

For the determination of splitting tensile strength of concrete, cylinder specimens of diameter to length ratio 1:2 was selected, with diameter as $150 \mathrm{~mm}$ and length as $300 \mathrm{~mm}$. Specimens were allowed for internal curing for $3,7,14,21 \& 28$ days and subjected to splitting tensile test under compression testing machine. The rate of loading was $0.5 \mathrm{kN} / \mathrm{s}$. While testing the specimens, plywood pieces are placed one at top and other at the bottom.

Table 8.3 Split Tensile Strength of Concrete

\begin{tabular}{|c|c|c|c|}
\hline \multirow{2}{*}{ S.no } & \multirow{2}{*}{ Mix } & \multicolumn{2}{|c|}{$\begin{array}{c}\% \text { of replacement (28 } \\
\text { days) }\end{array}$} \\
\hline & & $\begin{array}{c}20 \% \\
\text { replacement }\end{array}$ & $\begin{array}{c}30 \% \\
\text { replacement }\end{array}$ \\
\hline 1. & $\mathrm{M}_{20}$ & 3.5 & 4.4 \\
\hline 2. & $\mathrm{M}_{30}$ & 3.4 & 4.5 \\
\hline
\end{tabular}

Graph 3: Compressive strength for $20 \%$ replacement

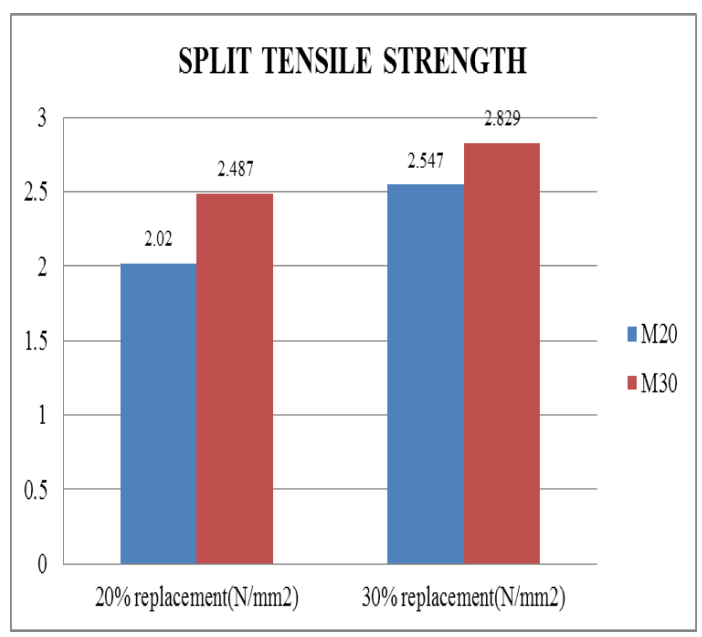

Table: 8.4 Modular Of Rupture

\begin{tabular}{|c|c|c|c|}
\hline \multirow{2}{*}{ S.no } & \multirow{2}{*}{ Mix } & \multicolumn{2}{|c|}{$\begin{array}{c}\text { \% oplacement (28 } \\
\text { days) }\end{array}$} \\
\cline { 3 - 4 } & & $\begin{array}{c}\mathbf{2 0 \%} \\
\text { replacement }\end{array}$ & $\begin{array}{c}\mathbf{3 0 \%} \\
\text { replacement }\end{array}$ \\
\hline 1. & $\mathrm{M}_{20}$ & 2.020 & 2.547 \\
\hline 2. & $\mathrm{M}_{30}$ & 2.487 & 2.829 \\
\hline
\end{tabular}

\section{CONCLUSIONS:}

1. The optimum dosage of PEG400 for maximum strengths (compressive, tensile and modulus of rupture) was found to be $1.5 \%$ for M20 and M30 grades of concrete.

2. Strength of self curing concrete is on par with conventional concrete.

3. Self curing concrete is the answer to many problems faced due to lack of proper curing.

\section{REFERENCES:}

1. Ambil, P.S and Rajamane N.P, (2009), "Self Curing Concrete - An Introduction", Concrete Composites Lab, Structural Engineering Research Centre, 2009.

2. Alvaro Paul and Mauricio Lopez, (2011), "Assessing Lightweight Aggregate Efficiency for Maximizing Internal Curing Performance", ACI Materials Journal, vol.108, 2011.

3. Bart Craeye, Matthew Geirnaerta and Geert De Schutter, (2011), "Super absorbing polymers as an internal curing agent for mitigation of early-age cracking of high-performance concrete bridge decks", Construction and Building Materials, vol.25, pp.1-13, 2011.

4. Bentz D.P, (2017), "Internal curing of high-performance blended cement mortars", ACI materials Journal vol.104, pp.408-414, 2007.

5. Dale P.Bentz, (2007), "Internal Curing of High-Performance Blended Cement Mortar", ACI Materials Journal, vol.104, 2007.

6. Daniel Cusson and Ted Hoogeveen, (2008), "Internal curing of highperformance concrete with pre-soaked fine light weight aggregate for prevention of autogenous shrinkage crackin", Cement and Concrete Research, vol.38, 2008. 


\section{International Journal of Engineering Applied Sciences and Technology, 2019 \\ Vol. 4, Issue 5, ISSN No. 2455-2143, Pages 252-258 \\ Published Online September 2019 in IJEAST (http://www.ijeast.com)}

7. El-Dieb. A.S,(2006), "Self - Curing concrete: Water retention, hydration and moisture transport", Construction and Building Materials. vol.21, pp.1282 1287, 2006.

8. Geiker, M.R. Bent, D.P. and Jensen, O.M, (2004) "Mitigating Autogeneous Shrinkage by Internal Curing", American Concrete Institute vol.218, pp.143-148, 2004.

9. Santha Kumar A.R, (2007) "Concrete Technology", Oxford University press 2007.

10. Shetty. M S, (2005), "Concrete Technology", S Chand Publishers, Revised edition 2005.

11. Muddassir Bora, Dhruv Vyas (2017), Self-Curing Concrete - Literature Review, 2017 IJEDR | Volume 5, Issue 1 | ISSN: 2321-9939.

12. Mohammed Shafeeque. (2016), Strength Comparison of Self-Curing Concrete and Normal Curing Concrete, VSSRG International Journal of Civil Engineering ( SSRG - IJCE ) - Volume 3 Issue 3March 2016.

13. Akshara O.S, DivyaSasi, (2016), An Experimental Study on Mechanical Properties of Self Curing Concrete, International Journal of Scientific \& Engineering Research, Volume 7, Issue 10, October-2016.

14. Ankith MK, (2014) Self Curing Concrete with Light Weight Aggregate, International Journal of Scientific Engineering and Research (IJSER)

15. Gaddam Sai Krishna,(2018) Experimental Study on Self - Curing Concrete with Red Mud and Quarry Dust, International Journal of Engineering Research And Management (IJERM) ISSN: 2349- 2058, Volume-05, Issue-03, March 2018.

16. Sunanda Nandakumar,(2018) Experimental Investigation on Self Curing Concrete with Partial Replacement of Cement with Metakaolin, IOSR Journal of Engineering (IOSRJEN) Vol. 08, Issue 6 (June. 2018).

17. IS: 10262-1982, Indian Standard Concrete Mix Proportioning - Guidelines, Bureau of Indian Standards, New Delhi

18. ShikhaTyagi, (2015) An Experimental Investigation of Self Curing Concrete Incorporated WithPolyethylene Glycol as Self Curing Agent"InternationalResearch Journal of Engineering and Technology (IRJET) e-
ISSN: 2395 -0056 p-ISSN: 2395-0072

Volume: 02 Issue: 06 | Sep-2015. 